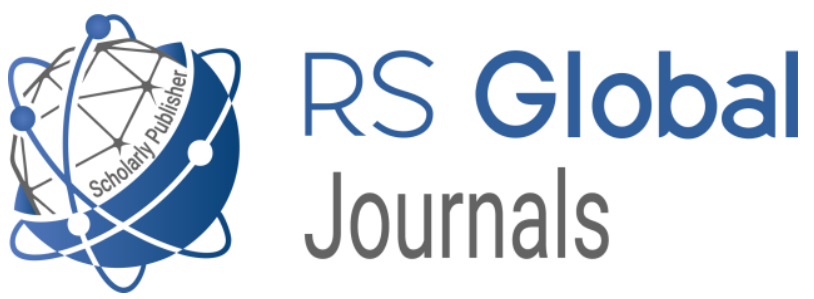

Scholarly Publisher

RS Global Sp. z O.O.

ISNI: 0000000484952390

Dolna 17, Warsaw, Poland 00-773

Tel: +48226022703

Email: editorial_office@rsglobal.pl

\begin{tabular}{ll} 
JOURNAL & World Science \\
\hline p-ISSN & $2413-1032$ \\
\hline e-ISSN & $2414-6404$ \\
\hline PUBLISHER & RS Global Sp. z O.O., Poland
\end{tabular}

ПРОФІЛАКТИКА РОТАЦІЇ ТОРИЧНИХ

ІНТРАОКУЛЯРНИХ ЛІНЗ ПІСЛЯ

ARTICLE TITLE $\quad$ ФАКОЕМУЛЬСИФІКАЦÏ̈ КАТАРАКТИ НА ОЧАХ 3

РОГІВКОВИМ АСТИГМАТИЗМОМ З ВИКОРИСТАННЯМ

СТАНДАРТНОГО КАПСУЛЬНОГО КІЛЬЦЯ

$\operatorname{AUTHOR}(\mathbf{S})$

Завгородня Наталія Григорівна, Новікова Валерія Юріївна, Цибульська Таміла Свгенівна

Nataliia Zavgorodnya, Valeriia Novikova, Tamila Tsybulska. (2021) Prevention of Toric Intraocular Lens Rotation After

ARTICLE INFO Cataract Phacoemulsification in the Eyes with Corneal Astigmatism Using a Standard Capsule Ring. World Science. 2(63). doi: 10.31435/rsglobal_ws/28022021/7443

DOI https://doi.org/10.31435/rsglobal_ws/28022021/7443

RECEIVED

21 December 2020

ACCEPTED

16 February 2021

PUBLISHED

21 February 2021

\title{
(c) (7)
}

LICENSE

This work is licensed under a Creative Commons Attribution

4.0 International License.

(C) The author(s) 2021. This publication is an open access article. 


\title{
ПРОФІЛАКТИКА РОТАЦЇ ТОРИЧНИХ ІНТРАОКУЛЯРНИХ ЛІНЗ ПІСЛЯ ФАКОЕМУЛЬСИФІКАЦЇ̈ КАТАРАКТИ НА ОЧАХ 3 РОГІВКОВИМ АСТИГМАТИЗМОМ 3 ВИКОРИСТАННЯМ СТАНДАРТНОГО КАПСУЛЬНОГО КІЛЬЦЯ
}

\author{
Завгородня Наталія Григорівна, д. мед. н., професор, зав. кафедрою офтальмології \\ Запорізького державного медичного університету, Запорізький державний медичний \\ університет, м. Запоріжжя, Україна, ORCID ID: https://orcid.org/0000-0002-5678-4196 \\ Новікова Валерія Юріївна, аспірант кафедри офтальмології Запорізького державного \\ медичного університету, Запорізький державний медичний університет, Запоріжжс, Украйна, \\ ORCID ID: https://orcid.org/0000-0002-6370-6348
}

Цибульська Таміла Євгенівна, д. мед. н., дочент кафедри офтальмології Запорізького державного медичного університету, Запорізький держсавний медичний університет, Запоріжжя, Україна, ORCID ID: https://orcid.org/0000-0002-1745-7002

DOI: https://doi.org/10.31435/rsglobal_ws/28022021/7443

\section{ARTICLE INFO}

Received: 21 December 2020

Accepted: 16 February 2021

Published: 21 February 2021

\section{KEYWORDS}

cataract, corneal astigmatism, cataract phacoemulsification, toric IOL, astigmatic correction.

\begin{abstract}
We have developed a method of preventing TIOL rotation by using a standard capsule ring. We examined 46 patients (59 eyes) who underwent phacoemulsification and implanted TIOL. Rotation of TIOL 6 months after surgery in the control group with 22 eyes (70.9\%), in the main group - with 12 eyes (42.85\%). In the main group in all cases, the deviation of the TIOL axis did not exceed 6 degrees. The proposed method of prevention of rotation of TIOL allows to increase the efficiency of phacoemulsification of cataracts.
\end{abstract}

Citation: Nataliia Zavgorodnya, Valeriia Novikova, Tamila Tsybulska. (2021) Prevention of Toric Intraocular Lens Rotation After Cataract Phacoemulsification in the Eyes with Corneal Astigmatism Using a Standard Capsule Ring. World Science. 2(63). doi: 10.31435/rsglobal_ws/28022021/7443

Copyright: (C) 2021 Nataliia Zavgorodnya, Valeriia Novikova, Tamila Tsybulska. This is an openaccess article distributed under the terms of the Creative Commons Attribution License (CC BY). The use, distribution or reproduction in other forums is permitted, provided the original author(s) or licensor are credited and that the original publication in this journal is cited, in accordance with accepted academic practice. No use, distribution or reproduction is permitted which does not comply with these terms.

Вступ. Факоемульсифікація катаракти сьогодні є найрозповсюдженішим оперативним втручанням на органах зору. Малоінвазивність, високотехнологічність та швидкість відновлення зорових функцій роблять дане оперативне втручання безпечним і таким, що не потребує госпіталізації [1]. Найбільшу дискусію серед факохірургів та науковців викликає питання корекції астигматизму, так як відомо, що близько $30 \%$ населення світу мають рогівковий астигматизм від 0,75 Д і вище, який призводить до зниження гостроти зору після факоемульсифікації катаракти [2].

Найбільш розповсюдженим методом корекції рогівкового астигматизму є імплантація торичних інтраокулярних лінз (ТІОЛ), що забезпечує короткий реабілітаційний період та високі функціональні результати [3, 4].

Головним критерієм отримання високої гостроти зору при імплантації ТІОЛ $є$ точне взаєморозташування астигматичного компоненту штучного кришталика та сильного меридіану рогівки. Розходження даних параметрів на $1^{\circ}$ знижує величину циліндричного компоненту лінзи на $3,3 \%$, а на $10^{\circ}$ - на $35 \%$ [5]. Окрім точної орієнтації ТІОЛ по вісі астигматизму під час операції, важливим фактором високої гостроти зору на таких очах є стабільність імплантованої торичної лінзи в післяопераційному періоді. Ротація ТІОЛ у віддалені строки після операції 
супроводжується значним зниженням гостроти зору та погіршенням його якості і потребує повторного оперативного втручання - репозиції ІОЛ.

Сьогодні триває пошук та розробка шляхів стабілізації торичних інтраокулярних лінз. Одним 3 таких $є$ розробка допоміжних методів та засобів за типом чи із застосуванням внутрішньокапсульного кільця $[6,7,8]$.

Більше 20 років застосовуються внутрішньокапсульні стабілізуючі кільця (за міжнародною абревіатурою «сарsule tension rings» (CTR)) при факоемульсифікації катаракти. Вони отримали широке розповсюдження як пристрої, що дозволяють хірургам розширити межі успішних ендокапсулярних втручань в першу чергу при ускладнених ситуаціях, таких як сублюксація кришталика з порушенням його зв'язкового апарату [8].

Нами розроблено спосіб профілактики ротації ТІОЛ з використанням стандартного капсульного кільця, який відрізняється тим, що кільце імплантується в капсульний мішок після імплантації ТІОЛ і виставлення ії відповідно сильного меридіану та розташовується поверх гаптичних елементів штучного кришталика (Патент України на корисну модель №145036, опубл. 10.11.2020, Бюл.№21) [9].

Мета роботи оцінити ефективність використання запропонованого способу профілактики ротації торичної інтраокулярної лінзи після факоемульсифікації катаракти на очах з рогівковим астигматизмом.

Матеріали і методи дослідження В роботі представлені результати дослідження, проведеного в клініці сучасної офтальмології «ВІЗУС», що $\epsilon$ клінічною базою кафедри офтальмології ЗДМУ. Проведене комплексне клініко-офтальмологічне обстеження 46 пацієнтів (59 очей), прооперованих 3 приводу катаракти та супутнього рогівкового астигматизму методом факоемульсифікації катаракти 3 імплантацією торичної ІОЛ. Сила супутнього рогівкового астигматизму становила від 0,5Д до 4,25Д за даними кератометрії (в середньому 1,96 \pm 0,1 Д). Вік пацієнтів коливався від 26 до 81 (середній вік - 54,3 \pm 1,74 роки). За статтю досліджувані хворі розподілялися майже нарівно: чоловіків було 27 (45,8\%), жінок - 32 (54,2\%). На 30 очах (51\%) мала місце незріла катаракта, на 22-х (37\%) - початкова, на 1 оці $(2 \%)$ - зріла, а на 6-ти очах (10\%) була виконана рефракційна заміна кришталика в зв'язку з аметропією та пресбіопією.

На всіх досліджуваних очах були імплантовані торичні інтраокулярні лінзи, найчастіше за вибором пацієнта: 27 - монофокальних (AT TORBI 709M/MP (Carl Zeiss Meditec, Німеччина) та AcrySof IQ Toric (Alcon, CШA)), 14 - біфокусних (AT LISA toric 909M (Carl Zeiss Meditec, Німеччина) та AcrySof IQ ReSTOR (Alcon, США)) та 18 трифокальних ТІОЛ (AT LISA tri toric 909M (Carl Zeiss Meditec, Німеччина). Пацієнти були прооперовані двома хірургами, індивідуальний індукований астигматизм яких не перевищував 0,25Д. Тунельний розріз виконувався в меридіані 160-180 градусів. На всіх очах операція та післяопераційний період перебігали без ускладнень. Термін спостереження становив 6 місяців після операції.

Всі прооперовані хворі були розподілені на 2 групи. В першу групу (контрольну) були віднесені 26 пацієнтів (31 око), де факоемульсифікація та імплантація торичної ІОЛ виконувалася за стандартною технікою без застосування методик, що перешкоджають ротації штучного кришталика в післяопераційному періоді. Другу групу (основну) склали 20 хворих (28 очей), що були прооперовані за запропонованою нами методикою [9].

На всіх очах до та після операції виконували ряд стандартних офтальмологічних обстежень (візометрія, авторефрактометрія на автоматичному рефрактометрі URK 700 (Unicos, Південна Корея), біомікроскопія, пряма офтальмоскопія, тонометрія, периметрія), ультразвукове А- та Всканування на апараті PACSCAN 300A SERIES (Sonomed, USA), ендотеліальна мікроскопія $з$ підрахунком кількості ендотеліальних клітин рогівки за допомогою приладу SP-3000P (TOPCON, Японія), оптична біометрія та розрахунок ІОЛ на апараті IOLMaster700 (Carl Zeiss, Німеччина). Гостроту зору визначали за системою Снеллена, результати представлені в десятинній системі. Додатково розрахунок торичної ІОЛ дублювався на апараті Verion ${ }^{\circledR}$ (Alcon, CША) та через використання он-лайн калькулятора «Z CALC Online IOL Calculator» (Carl Zeiss, Німеччина).

Статистичну обробку виконували за допомогою пакета програм Statistica 13.0, номер ліцензії JPZ8041382130ARCN10-J. Проводився розрахунок середньої арифметичної варіаційного ряду (M) та iï стандартної помилки (m). Для порівняння кількісних величин в парних рядах використовували t-критерій Стьюдента з попередньою перевіркою гіпотези про нормальність розподілу змінних (Shapiro-Wilk W test) в варіаційному ряду. При відсутності нормального розподілу величин в досліджуваних вибірках застосовувався непараметричний критерій Манна-Уїтні. Відмінності вважали статистично вірогідними при значенні $\mathrm{p}<0,05$. 
Результати. Головним критерієм ефективності факоемульсифікації катаракти у хворих з супутнім рогівковим астигматизмом є висока гострота зору без циліндричної корекції та іiі збереження в післяопераційному періоді, що досягається стабільністю положення ТІОЛ в капсульному мішку. На рис.1 представлені середні показники гостроти зору після оперативного втручання в першій (контрольній) та другій (основній) групах в динаміці.

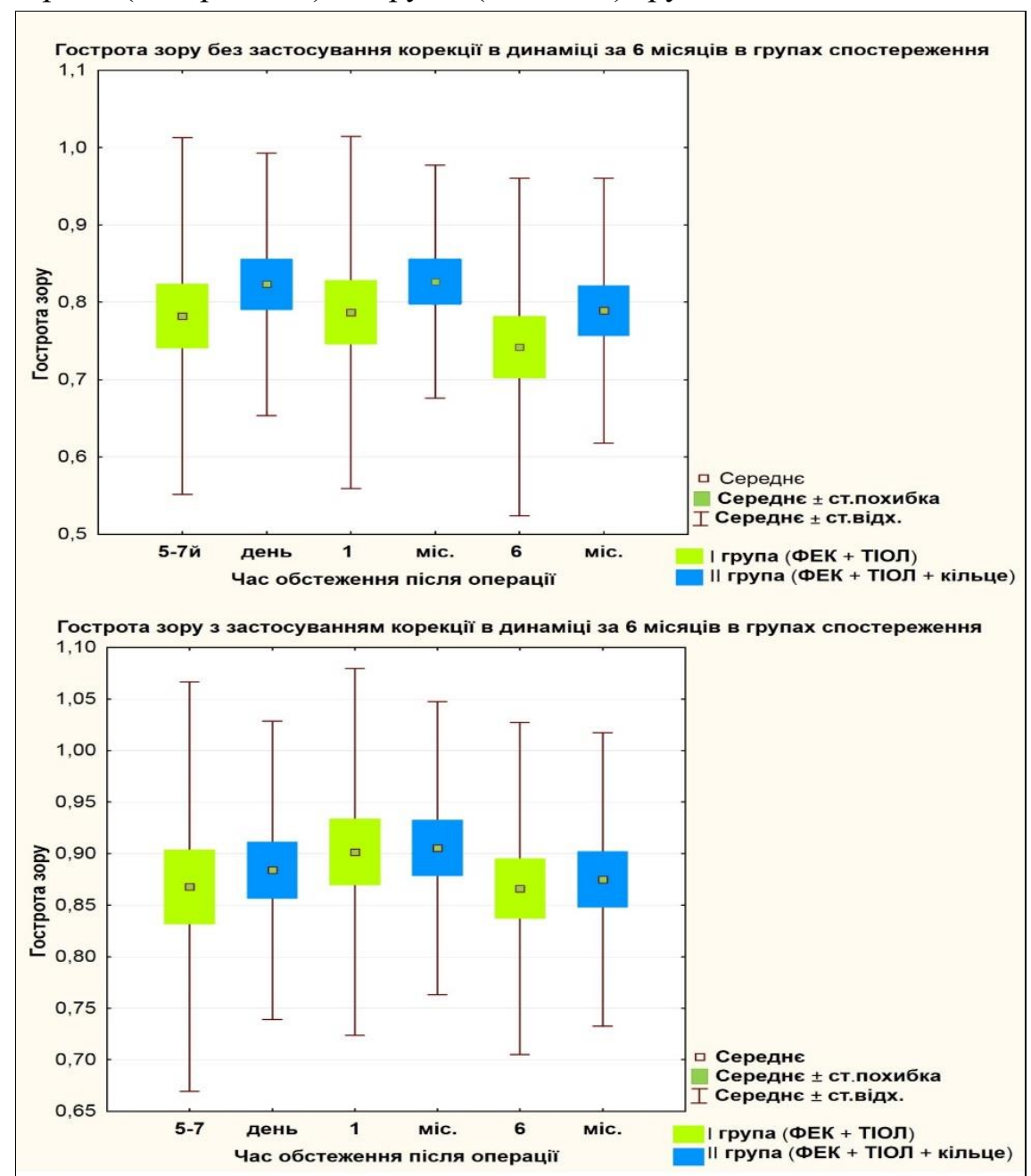

Рис. 1. Показники гостроти зору після ФЕК з імплантаџією ТІОЛ в групах спостереження через 5-7 днів, 1 місяиь та 6 міс. після операції

Примітка: різниця з відповідними показниками між групами у всіх випадках не достовірна, p>0,05.

Як видно з представлених діаграм, середні показники гостроти зору між групами різняться в межах одного рядка, але важливим $\epsilon$ те, що розбіг результатів, які ми оцінюємо за вусами шкали розмаху - менш виражений саме в основній групі, де застосовувалась імплантація внутрішньокапсульного кільця. Також помітно, що різниця за середніми показниками гостроти зору без застосування корекції збільшувалась з часом після операції. Так через 6 міс. після операції середні значення гостроти зору без застосування корекції у першій групі - 0,74 $\pm 0,03, \mathrm{y}$ другій $-0,78 \pm 0,03$. В першій групі на 13 очах (41,93\%) через 6 місяців після операції зберігалася максимальна гострота зору $(0,9$ та вище), в 14ти випадках $(45,16 \%)$ корекція не була потрібна для покращення рефракційного результату, на 4 очах (12,9\%) була необхідна сферична корекція, на 12 очах (38,7 \%) - циліндрична, на 1оці (3,2 \%) - сферо-циліндрична.

В другій групі, де застосовувалась запропонована методика імплантації внутрішньокапсульного кільця поверх ТІОЛ, через 6 місяців гострота зору 0,9-1,0 зберігалась на 14 очах $(50,0 \%)$, в 14ти випадках $(50,0 \%)$ корекція не була потрібна для покращення рефракційного результату, на 4 очах $(14,2 \%)$ покращувала гостроту зору сферична корекція, на $5(17,8 \%)$ - циліндрична, в 5 випадках $(17,8 \%)$ знадобилась сферо-циліндрична корекція.

Як правило, ротацію ТІОЛ оцінюють за динамікою гостроти зору та відповідності осі лінзи до такої під час імплантації. В таблиці 1 наведені результати досягнення максимальної 
гостроти зору в основній та контрольній групах через 1 та 6 місяців. Більш ранні результати вважали непоказовими для оцінки стабільності ТІОЛ в капсульному мішку.

Таблиця 1. Динаміка гостроти зору на очах з катарактою та рогівковим астигматизмом після ФЕК з імплантацією ТІОЛ в групах спостереження.

\begin{tabular}{|l|c|c|c|c|c|c|}
\hline \multirow{2}{*}{$\begin{array}{c}\text { Строки } \\
\text { спостереження }\end{array}$} & \multicolumn{7}{|c|}{ Гострота зору } \\
\cline { 2 - 7 } & $\begin{array}{c}0,9-1,0 \text { (кількість очей, \%) } \\
\text { Основна } \\
\text { група }\end{array}$ & $\begin{array}{c}\text { Контрольна } \\
\text { група }\end{array}$ & $\begin{array}{c}\text { Основна } \\
\text { група }\end{array}$ & $\begin{array}{c}\text { Контрольна } \\
\text { група }\end{array}$ & $\begin{array}{c}\text { Основна } \\
\text { група }\end{array}$ & $\begin{array}{c}\text { Контрольна } \\
\text { група }\end{array}$ \\
\hline 1 місяць & $13(46,4 \%)$ & $14(45,1 \%)$ & $11(39,2 \%)$ & $9(29,0 \%)$ & $4(14,2 \%)$ & $8(25,8 \%)$ \\
\hline 6 місяців & $14(50 \%)$ & $13(41,9 \%)$ & $8(28,5 \%)$ & $8(25,8 \%)$ & $6(21,42 \%)$ & $10(32,2 \%)$ \\
\hline
\end{tabular}

3 таблиці видно, що відсоток очей в контрольній групі, які мали гостроту зору від 0,7 та вище через 1 міс після операції склав 74,1\% (23 ока), а через 6 місяців після операції - 67,7\% (21 око). В той час як в основній групі через 1 місяць після ФЕК + ТІОЛ на 24 очах $(85,6 \%)$. була досягнута висока гострота зору (0,7 та вище). Різниця між показниками гостроти зору за групами спостереження не була статистично значимою ( $>0,05)$. Зменшення кількості очей 3 високими показниками гостроти зору через 6 місяців в основній групі до 22 (78,5\%) було зумовлено розвитком вторинної катаракти на 2 очах.

В подальшому проведений аналіз стабільності положення ТІОЛ в капсульному мішку протягом часу. Для цього порівнювали вісь імплантації лінзи та іiі положення станом через 6 місяців післяопераційно. Положення внутрішньоочної лінзи оцінювали за допомогою щілинної лампи та розміщення світлового пучка паралельно насічок на ТІОЛ на прооперованому оці. Через 6 місяців після операції ротація інтраокулярної лінзи виявлена в контрольній групі на 22 очах (70,9\%), в основній групі - на 12 очах (42,85\%). Причому в контрольній групі в більшості випадків (на 13 очах, 59 \% з числа ротованих) було зафіксоване відхилення вісі інтраокулярної лінзи в межах 6 градусів і більше, в той час, як в основній групі у всіх випадках (12 очей, $100 \%$ 3 ротованих) відхилення вісі імплантації лінзи не перевищувало 6 градусів.

На рисунку 2 представлені результати відхилення вісі ТІОЛ через 6 місяців після операції в основній та контрольній групах.

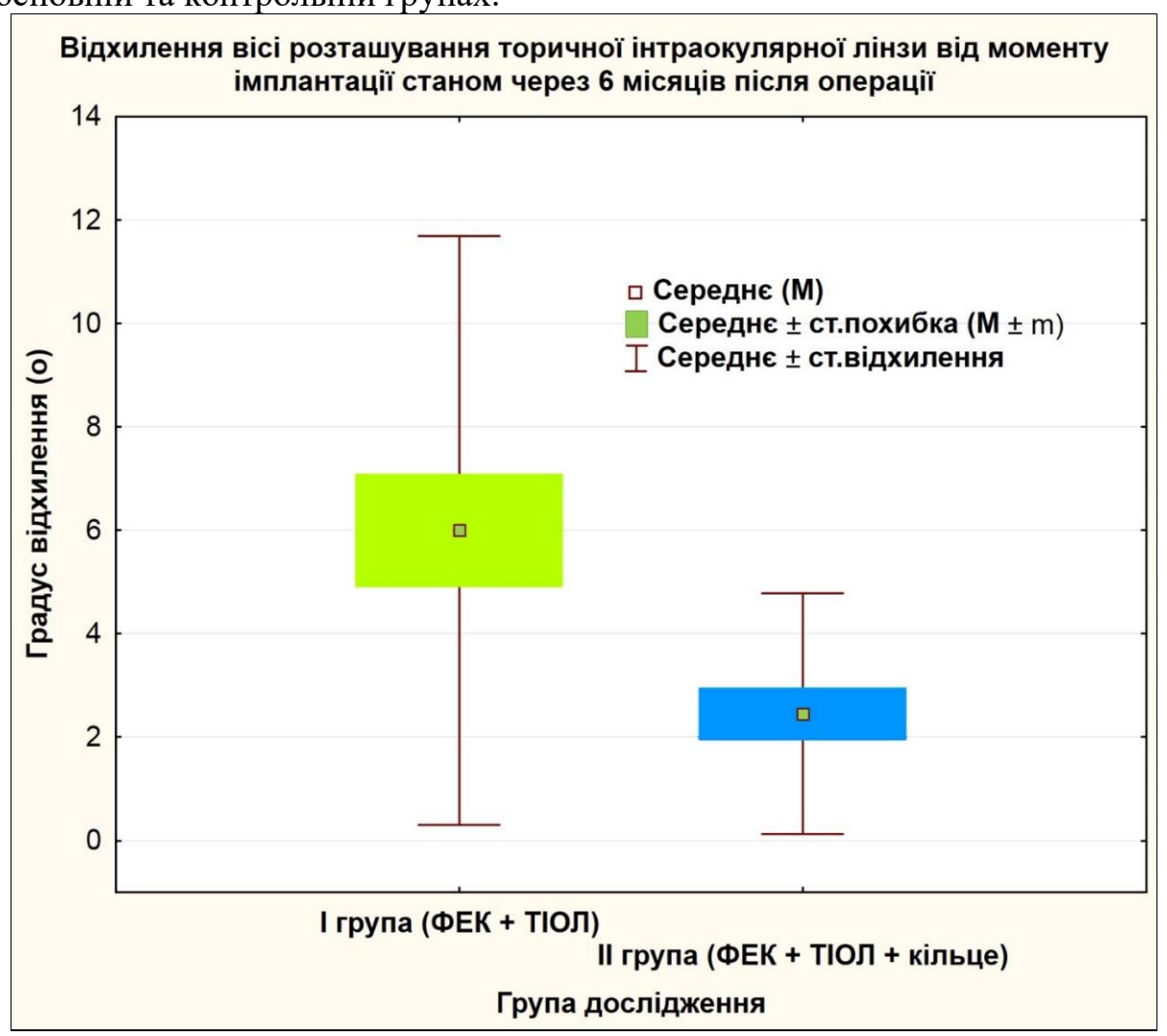

Рис.2. Середні значення та розбіг показників відхилення вісі положення торичної інтраокулярної лінзи через 6 міс. після ФЕК в досліджуваних групах (p<0,05). 
Аналізуючи отримані дані можна сказати, що положення ТІОЛ у групі, де додатково імплантувалось внутрішньокапсульне кільце за запропонованою методикою, було більш стабільне, лінза зберігала своє висхідне положення краще, а саме середній показник відхилення був на рівні $2,14 \pm 0,4$ градуси $\left(\right.$ мах $\left.-6^{\circ}, \min -0^{\circ}\right)$, що не мало суттєвого значення для зорових функцій.

В той же час в контрольній групі групі середній показник відхилення становив $5,41 \pm 1,01$ градуси $\left(\right.$ мах $\left.-30^{\circ}, \min -0^{\circ}\right)$, що впливало на гостроту зору та суб'єктивні відчуття дискомфорт, двоїння i неможливість бачити на близькій відстані при імплантованій мультифокальній ТІОЛ. Різниця між середнім показником відхилення вісі імплантації торичної лінзи в контрольній групі є статистично достовірною ( $<0,05)$.

Слід зауважити, що в 2 випадках пацієнти 3 першої групи спостереження потребували повторного оперативного втручання з причини значної ротації ТІОЛ.

\section{Клінічні приклади:}

1. Пацієнтка Д., 1961 р.н., оперована 3 приводу встановленого діагнозу: «Незріла катаракта, складний міопічний астигматизм правого ока».

Висхідний астигматизм - 2,75 Д. Імплантована ТІОЛ - AT Torbi 709 M (Carl Zeiss Meditec, Німеччина) через 1 місяць після операції потребувала додаткової циліндричної корекції у 1,5 Д. На плановому огляді виявлено, що лінза ротувалась на 30 градусів на фоні виражених фіброзних змін капсульного мішка. Гострота зору знизилась до 0,5 без корекції, з додатковою корекцією sph -0,5D та cyl +1,5D дорівнювала 1,0. Хвора скаржилася на нечіткість зору, двоїння, незадоволення результатом оперативного лікування. Пацієнтка була прооперована: інтраокулярна лінза була повернута в висхідне положення, згідно передопераційного розрахунку та стабілізована за допомогою імплантації в капсульний мішок поверх гаптичних елементів ТІОЛ стандартного розімкнутого кільця діаметром 13 мм із закругленими кінцями. При огляді на 1 -у добу після операції гострота зору дорівнювала 1.0 (через діафрагму), внутрішньоочний тиск в нормі, ІОЛ розташована в капсульному мішку і займає правильне положення. Через 6 міс. після повторної операції гострота зору прооперованого ока $=1.0$, внутрішньоочний тиск в нормі, положення ТІОЛ стабільне, ротації не виявлено.

2. Пацієнтка Н., 1967 р.н., оперована з приводу встановленого діагнозу: «Початкова катаракта лівого ока. Міопія середнього ступеню, складний міопічний астигматизм лівого ока».

Висхідний астигматизм - 2,25 Д. Імплантована ТІОЛ - AT LISA tri toric 909M (Carl Zeiss Meditec, Німеччина). Цей випадок цікавий тим, що пацієнтка потребувала двох додаткових втручань. При першому втручанні виконана репозиція ротованої на 20 градусів лінзи стандартним способом: ТІОЛ була повернута в висхідне положення згідно передопераційного розрахунку. На другий день гострота зору оперованого ока становила 0,95 через діафрагму, на 7й день Vis OS - 0,7 не корегує. Знову з'явились скарги на двоїння та нечіткість зору, неможливість читати на близькій відстані. При огляді виявлено, що ТІОЛ повернулась в положення до репозиції. Пацієнтка потребувала повторного оперативного втручання. Під час операції виявлено фіброзні зміни капсульного мішка, які і призводили до зміни положення гаптичного елементу, що викликало повторне зміщення лінзи. Друга репозиція виконана з використанням додаткового капсульного кільця за запропонованим нами способом для досягнення максимальної стабільності положення лінзи. Через 6 місяців після повторної операції гострота зору оперованого ока становила 100\%, внутрішньоочний тиск в нормі, положення ТІОЛ стабільне.

Обговорення. Офтальмохірурги у всьому світі намагаються вирішити питання ротації та стабільності положення торичної інтраокулярної лінзи у капсульному мішку у їі висхідній запланованій вісі. Так Г.А. Федоров та В.В. Егоров розробили пристрій для підвищення ротаційної стабільності торичних інтраокулярних лінз, який мав вигляд незамкнутого плоского капсульного кільця 3 двома шарнірами на кінцях і м'яким стопором в формі циліндра в центральній частині кільця. Дане кільце після імплантації обертають всередині капсульного мішка за годинниковою стрілкою до тих пір, поки положення стопора не співпаде з відміткою на рогівці, що позначає положення сильного меридіана астигматизму. Потім в капсульний мішок імплантують ТІОЛ і обертають ії за годинниковою стрілкою та розташовують з упором основи її опорного елемента в силіконовий стопор, що в сукупності повинно відповідати вісі астигматизму [6]. Даний спосіб добре стабілізував лінзу та мав суттєві недоліки. По-перше не було налагоджено широке промислове виробництво такого кільця, що перешкоджало широкому впровадженню в практику, по-друге виникали певні складнощі при імплантації 
вказаного капсульного кільця, особливо при недостатній ширині зіниці, щоб силіконовий стопор зайняв правильну вісь з урахуванням надалі імплантованої ТІОЛ.

Кузнєцов С.Л. и Галлєєв Т.Р. зі співавторами також розробили внутрішньокапсульне кільце, особливістю якого була наявність на внутрішній поверхні еластичних елементів у вигляді трьох зубців з зазорами, для фіксації гаптичного елементу імплантованої надалі ТІОЛ за типом «скрепки» $[7,8] .3$ недоліків можна продублювати вищевказані для попереднього пристрою.

Одержані дані та наведені клінічні приклади свідчать про те, що імплантація додаткового капсульного кільця за запропонованою нами методикою перешкоджає ротації торичної лінзи в капсульному мішку. На наш погляд це відбувається завдяки двом ефектам: 1) капсульне кільце стабілізує капсульний мішок та запобігає його деформації при розвитку фіброзних процесів та 2) додатковий тиск кільця на гаптичні елементи ТІОЛ також зменшує вірогідність ротації та вільного пересування лінзи у капсульному мішку.

Слід зауважити, що в роботах Vokrojová M, Havlíčková L, Brožková M та Hlinomazová Z. не виявлено достовірної різниці в ротаційній стабільності імплантованого кришталика 3 наявністю або відсутністю внутрішньокапсульного кільця [10]. Отримані нами дані про більшу стабільність торичної інтраокулярної лінзи при імплантації стандартного капсульного кільця обгрунтовуються саме етапністю імплантації лінзи та капсульного кільця. Запропонована нами методика відрізняється тим, що додатково фіксує гаптичні елементи саме імплантованим поверх них капсульним кільцем.

Висновки. Таким чином можна зробити наступні висновки:

1. Запропонований спосіб профілактики ротації торичної інтраокулярної лінзи в капсульному мішку 3 використанням стандартного капсульного кільця, що імплантується поверх гаптичних опорних елементів штучного кришталика, дозволяє підвищити ефективність хірургічного лікування катаракти на очах 3 рогівковим астигматизмом, забезпечує довготривалий стабільний результат зорових функцій, знижує частоту повторних оперативних втручань 3 приводу репозиції ротованої торичної інтраокулярної лінзи та може бути рекомендований для використання у практиці катарактальних хірургів.

2. Використання стандартного капсульного кільця за запропонованою методикою дозволяе запобігти ротації торичної інтраокулярної лінзи більше, ніж на 6 градусів в 100\% випадків, що суттєво не впливає на гостроту зору та не потребує додаткових оперативних втручань.

3. Представлений спосіб профілактики ротації торичної інтраокулярної лінзи дозволяє досягти високої гостроти в $85,6 \%$ випадків.

\section{ЛІТЕРАТУРА}

1. Leaming, D. (2004), «Practice styles and preferences of ASCRS members - 2003 survey», Journal of Cataract \& Refractive Surgery, 30, 892-900. Retrieved from https://doi.org/10.1016/j.jcrs.2004.02.064

2. Хрипун К.В., (2016), Хирургическая коррекция астигматизма во время и после экстракции катаракты: дис. канд. мед. наук: 14.01.07. Санкт-Петербург.

3. Мельник B.O., (2012) Досвід імплантації інтраокулярних линз AcrySof IQ Toric при факоемульсификації катаракт у хворих з високим ступенем астигматизму. Материали научно-практической конференции офтальмологов с международным участием «Филатовские чтения» 24-25 мая 2012 года, Одеса, 74.

4. Бачук Н. Ю., (2013) «Опыт имплантации торических интраокулярных линз у больных катарактами с роговичным астигматизмом», Международный медицинский журнал, 1, 112-117.

5. Ильинская И.А., (2014) Клинические аспекты интраокулярной коррекции астигматизма: дис. канд. мед. наук: 14.01.07. Москва.

6. Федоров Г. А., (2011), «Устройство для повышения ротационной стабильности торических ИОЛ в капсульном мешке после проведения факоэмульсификации», Современные технологии катарактальной и рефракционной хирургии. Retrieved from https://eyepress.ru/article.aspx?9755 6

7. Кузнєцов С.Л., Галлєєв Т.Р., (2010), «Имплантации внутрикапсульного кольца с элементами фиксации ИОЛ с плоскостной гаптикой» Экспериментально-клиническое изучение. Вестник ОГУ, 12, 124-127.

8. Кузнецов С.Л., (2014), «Опыт применения внутрикапульных стабилизирующих колец для фиксации интраокулярной линзы в оптико-реконструктивной хирургии», Медицинский вестник Башкортостана, 9 (2), 101-104.

9. Завгородня Н.Г., Новікова В.Ю., Патент України на корисну модель №145036, Спосіб профілактики ротації торичної інтраокулярної лінзи після факоемульсифікації катаракти на очах з рогівковим астигматизмом. опубл. 10.11.2020, Бюл. №21

10. Vokrojová M, and Havličková L, Brožková M, Hlinomazová Z., (2020), «Effect of Capsular Tension Ring Implantation on Postoperative Rotational Stability of a Toric Intraocular Lens», Journal of Cataract \& Refractive Surgery, 36(3), 186-192. Retrieved from https://doi.org/10.3928/1081597X-20200120-01 